XIAOQIONG WANG

Chongqing University of Technology, Chongqing, China

20120035@cqut.edu.cn

IRENA KAŁUŻYŃSKA

University of Warsaw, Warsaw, Poland

i.s.kaluzynska@uw.edu.pl

https://orcid.org/0000-0001-6043-5557
DOI: http://dx.doi.org/10.17651/ONOMAST.63.13

Onomastica LXIII, 2019

PL ISSN 0078-4648

\title{
CONTEMPORARY BY-NAMES OF CHINESE PLACES
}

Keywords: Chinese place names, Chinese by-names, structure of Chinese by-names, semantic features of Chinese by-names, honorific titles of places

\section{INTRODUCTION}

The Chinese earliest toponymic records found in oracle-bone inscriptions are about 3,000 years old (the late period of the Shang Dynasty) (Chen, 1965). However, the "Shanhai Jing 山海经 [Mountains and Rivers]" and "Yugong 禹贡 [Tribute to Yu]" written about 2,500 years ago in the Warring States Period (480 B.C. -221 B.C.) mark the real start of Chinese toponymic exploration (Chen, 2012). After that, the research on the records and confirmation of original place names has been a constant. Many important geographical works have appeared in this time, like "Hanshu. Dili Zhi 汉书·地理志 [History of the Former Han Dynasty: Geographical Records]" and "Shuijing Zhu 水经注 [Notes on Waterways]" by Li Daoyuan in the Northern Wei Dynasty (317-533). Over the next 2,500 years, along with the countless changes of Chinese dynasties, the traditional research on Chinese place names continued with numerous achievements. The main toponomastic activities in recent years have been the compilation of toponymic dictionaries (Chen, 2012; Niu, 2016; Shi, 2017), toponymic regulation and standardization (Shi, 1994; Wang, 2015), the adoption of a uniform transcription of Chinese place names and the construction of GIS (Geographic Information System) (Wang, 2016).

The European interest in Chinese places and place names can be traced to over 700 years ago. Marco Polo (1254-1324), an Italian merchant, was the first man to introduce China to Europe with his travel notes "The Travels of Marco Polo" (completed in 1299). His vivid account of Chinese history, culture and geography aroused the interest of Europeans in China. However, the professional research related to Chinese place names only began about one hundred years ago, as evidenced by works such as the series "Science and Civilisation in China" written by the British scientist Joseph Needham in the years 1954-1959

This is an Open Access article available at: https://onomastica.ijp.pan.pl, https://rcin.org.pl 
(Needham, 1959), some toponymic monographs, e.g. "The Cities and Towns of China. A Geographical Dictionary" (Playfair, 1910), "Comprehensive Geography of the Chinese Empire" (Richard, 1908) and "Contemporary Chinese Place Names. Names of Administrative Divisions at County and City Level" (Kałużyńska, 2002). There have also been some important articles on the subject, such as "Chinese Place Names and the Appreciation of Geographic Realities" (Spencer, 1941).

The above comprehensive toponymic studies mostly concern Chinese official place names in different historical periods and seldom discuss by-names, because the latter vary in frequency and stability, and have less referable historical records. The purpose of this paper is to discuss the properties of by-names that distinguish them from official names, to analyse their structural and semantic features and to search for the historical evidence of by-names.

\section{CHINESE DEFINITIONS OF BY-NAMES}

In some authoritative Chinese dictionaries, the terms biecheng 别称 or bieming 别名, literally 'other names', and here specifically called 'by-names' ${ }^{1}$ are generally defined as informal names, different from formal ones. This concept is illustrated in "Hanyu Da Cidian 汉语大词典 [Great Chinese Dictionary]" (HDC, 2011): ${ }^{2}$

(Biecheng) Zhengshi mingcheng yiwai de bieming. Fen Chengjun Xiyu Diming. Xuli: "Ciwai bu changjian de mingcheng, bifang Shanguo (Scham) dui yin caizi dewen, Salakesi (Tcherkesses) zhi biecheng caizi fawen." You ru: Xiang shi Hunan de biecheng, Lu shi Shandong de biecheng.

【别称】正式名称以外的别名。冯承钧《〈西域地名〉序例》: “此外不常见的名称, 比方苫国 (Scham) 对音采自德文, 撒刺克思 (Tcherkesses) 之别称采自法文。”又 如: 湘是湖南的别称, 鲁是山东的别称。

(Biecheng) Additional names for formal names. Fei Chengjun said in the "Preface to Xiyu Diming": "They are rarely met names, for example, the transcription Scham comes from German, while biecheng Tcherkesses comes from French". More examples are: Xiang is the biecheng of Hunan and $\mathrm{Lu}$ is the biecheng of Shandong.

1 The term 'by-name' is defined in the List of Key Onomastic Terms of International Council of Onomastic Sciences, as the following: "by-name: informal, additional name of a person, a place, an object etc. - e.g. John Brown alias Shorty in English', Juana Martinéz alias Morena in Spanish, Staffan Nyström alias Lane in Swedish, Big Apple for New York, Big Blue for IBM”, https:// icosweb.net/wp/wp-content/uploads/2019/05/ICOS-Terms-en.pdf.

2 The linking writing for Chinese Pinyin, the official romanization system for Standard Chinese, in this paper bases on the latest revised edition "Zhonghua Renmin Gongheguo Guojia Biaozhun: Hanyu Pinyin Zhengcifa Jiben Guize 《中华人民共和国国家标准·汉语拼音正词法基 本规则》 [Basic Rules of the Chinese Phonetic Alphabet Orthography of the National Standard of the People's Republic of China]", code: GB/T16159-2012, released in June, 2012. 
The above definitions are also adopted by "Xiandai Hanyu Cidian 现代汉 语词典[Modern Chinese Dictionary]" (XHC, 2016). The dictionary considers all the so-called informal, rarely met names such as transliterated names, short names etc. as biecheng and contrasts them with formal names.

However, numerous biecheng, by-names, transliterated names and short names are quite popular in China and not rarely met at all. Almost every Chinese person knows that Mountain City is a biecheng of the Chongqing Municipality. Some transliterated names which are just their formal names (e.g.: Lhasa is the pronunciation in Tibetan), and all the short names of Chinese administrative regions can definitely be used in formal occasions (e.g.: Jing is a short name of Beijing). Therefore, different groups of Chinese biecheng should not be regarded as informal names and should instead be classified according to their exclusive characteristics. Considering the confusing definitions of these Chinese place names, the first step is to redefine and ascertain the different characteristics of them.

\subsection{Full names, short names, historical names and by-names}

In contemporary China there are 34 provincial administrative regions which have their own full names, short names and historical names. ${ }^{3}$ The data concerning full names and short names in Table 1 come from the latest version of the register compiled by China's Ministry of Civil Affairs, historical names with statistic data are referenced in local chronicles, and by-names come from Chinese real life and the popular online data baidu wenku 百度文库 'Baidu library': ${ }^{4}$

Table 1: The names of the 34 provincial administrative regions

\begin{tabular}{|c|c|c|c|c|}
\hline \multirow{2}{*}{$\stackrel{\mathscr{0}}{\mathscr{0}}$} & \multicolumn{3}{|c|}{ Contemporary } & \multirow{2}{*}{\begin{tabular}{|c|} 
Historical \\
$\begin{array}{c}\text { Official Names / } \\
\text { By-Names }\end{array}$ \\
\end{tabular}} \\
\hline & Full Names & Short Names & By-Names & \\
\hline \multirow{4}{*}{ 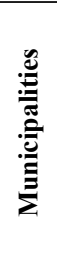 } & Beijing 北京 & Jing 京 & $\begin{array}{l}\text { Shou Du 首都, Jing Cheng 京城, } \\
\text { Huang Cheng 皇城 }\end{array}$ & Beijing 北京 $(18)^{5}$ \\
\hline & Tianjin 天津 & Jin 津 & Bohai Mingzhu 渤海明珠 & Tianjin 天津 (8) \\
\hline & Shanghai 上海 & $\mathrm{Hu}$ 沪 & $\begin{array}{l}\text { Mo Du 魔都, Buye Cheng 不夜 } \\
\text { 城, Donfang Mingzhu 东方明珠 }\end{array}$ & $\begin{array}{l}\text { Shanghai } \\
\text { 上海 (9) }\end{array}$ \\
\hline & Chongqing 重庆 & Yu 渝 & Shan Cheng 山城, Wu Du 雾都 & $\begin{array}{l}\text { Chongqing } \\
\text { 重庆 (5) }\end{array}$ \\
\hline
\end{tabular}

3 The historical names in this paper refer to the names used before the establishment of the People's Republic of China in 1949.

4 The website is: https://wenku.baidu.com/.

5 The number in parentheses indicates the total number of historical names used in various periods. The names listed are only some selected examples. 


\begin{tabular}{|c|c|c|c|c|}
\hline \multirow{2}{*}{ 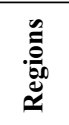 } & \multicolumn{3}{|c|}{ Contemporary } & \multirow{2}{*}{$\begin{array}{c}\text { Historical } \\
\begin{array}{c}\text { Official Names / } \\
\text { By-Names }\end{array}\end{array}$} \\
\hline & Full Names & Short Names & By-Names & \\
\hline \multirow{23}{*}{ 递 } & Hebei 河北 & $\mathrm{Ji}$ 冀 & & No data available \\
\hline & Shanxi 山西 & Jin 晋 & & No data available \\
\hline & Liaoning 辽宁 & Liao 辽 & & No data available \\
\hline & Jilin 吉林 & $\mathrm{Ji}$ 吉 & & No data available \\
\hline & Heilongjiang 黑龙江 & Hei 黑 & & No data available \\
\hline & Jiangsu 江苏 & $\mathrm{Su}$ 苏 & & No data available \\
\hline & Zhejiang 浙江 & Zhe 浙 & & No data available \\
\hline & Anhui 安徽 & Wan 皖 & & No data available \\
\hline & Fujian 福建 & Min 闽 & & No data available \\
\hline & Jiangxi 江西 & Gan 赣 & & No data available \\
\hline & Shandong 山东 & $\mathrm{Lu}$ 鲁 & & No data available \\
\hline & Henan 河南 & Yu 豫 & & No data available \\
\hline & Hubei 湖北 & $\mathrm{E}$ 鄂 & Qianhu zhi Sheng 千湖之省 & No data available \\
\hline & Hunan 湖南 & Xiang 湘 & Furong Guo 芙蓉国 & No data available \\
\hline & Guangdong 广东 & Yue 粤 & & No data available \\
\hline & Taiwan 台湾 & Tai 台 & Bao Dao 宝岛 & Taiwan 台湾 (9) \\
\hline & \begin{tabular}{|l|} 
Sichuan 四川 \\
\end{tabular} & Chuan 川, Shu 蜀 & Tianfu zhi Guo 天府之国 & Sichuan 四川 (6) \\
\hline & Guizhou 贵州 & Gui 贵, Qian 黔 & & No data available \\
\hline & Yunnan 云南 & Yun 云, Dian 滇 & & No data available \\
\hline & \begin{tabular}{|l} 
Shaanxi 陕西 \\
\end{tabular} & Shan 陕, Qing 秦 & & No data available \\
\hline & Gansu 甘肃 & Gan 甘, Long 陇 & & No data available \\
\hline & Qinghai 青海 & Qing 青 & & No data available \\
\hline & Hainan 海南 & Qiong 琼 & Qiongtai 琼台, Qiongya 琼崖 & Hainan 海南 (13) \\
\hline \multirow{5}{*}{ 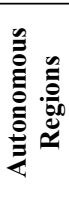 } & Neimenggu 内蒙古 & Meng 蒙 & & No data available \\
\hline & Guangxi 广西 & Gui 桂 & & No data available \\
\hline & Xizang 西藏 & Zang 藏 & & No data available \\
\hline & \begin{tabular}{|l} 
Ningxia 宁夏 \\
\end{tabular} & Ning 宁 & & No data available \\
\hline & Xinjiang 新疆 & Xin 新 & & No data available \\
\hline \multirow{2}{*}{ 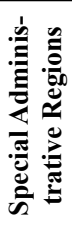 } & Xianggang $^{6}$ 香港 & Gang 港 & Xiang Jiang 香江 & \begin{tabular}{|l} 
Xianggang 香港 \\
\end{tabular} \\
\hline & Aomen $^{7}$ 澳门 & Ao 澳 & Du Cheng 奢城, Lian Dao 莲岛 & Aomen澳门(5) \\
\hline
\end{tabular}

Historical names, which include historical official names and historical bynames, would not be presented here if there were no need to do so. The common historical names of some places collected in Table 1 are presented below:

6 Hongkong is the name in Guangdong dialect, Xianggang in Standard Chinese.

7 Macau is the name in Portuguese, Aomen in Standard Chinese. 
Beijing 北京 (18): Jiguo 蓟国, Yuji 于蓟, Yandu 燕都, Yanjing 燕京, Youzhou 幽州, Guangyang Jun 广阳郡, Yanguo 燕国, Yanjun 燕郡, Zhuojun 溷郡, Youdu $\mathrm{Fu}$ 幽都府, Xijin $\mathrm{Fu}$ 析津府, Zhongdu 中都, Daxing $\mathrm{Fu}$ 大兴府, Dadu $\mathrm{Lu}$ 大都路, Beiping Fu 北平府, Xingzai 行在, Beijing 北京, Jingshi Shuntian $\mathrm{Fu}$ 京师顺天府.

Tianjin 天津 (8): Zhigu Zhai 直沽寨, Haijin Zhen 海津镇, Tianjin 天津, Tianjin Wei 天津卫, Tianjin Zhou 天津州, Tianjin Fu 天津府, Zhidi 直隶, Baihe 白河.

Shanghai 上海 (9): Huatinghai 华亭海, Shanghai Zhen 上海镇, Shanghai County 上海县, Shenjiang 申江, Chunshen 春申, Hushang 沪上, Songhu 淞沪, Hudu 沪渎, Songbin 淞滨.

Chongqing 重庆 (5): Jiangzhou 江州, Bajun 巴郡, Yuzhou 渝州, Gongzhou 恭州, Chongqing 重庆.

Taiwan 台湾 (9): Taoyi 岛夷, Dongkun 东鲲, Yizhou 夷州, Liuqiu 流求, Liuqiu 流球/Liuqiu 瑠求, Taiwan 台湾, Taiwan Fu 台湾府, Taiwan Xingsheng 台湾行省, Taiwan Sheng 台湾省.

Sichuan 四川 (6): Bashu 巴蜀, Shu 蜀, Cancong 虫丛, Shujun蜀郡, Chuanxia Silu 川峡四路, Sichuan 四川.

Hainan 海南 (13): Zhuya 珠崖, Tan'er 儋耳, Yazhou崖州, Linzhen 临振, Tanzhou 儋州, Yazhou 崖州, Zhenzhou 振州, Wanzhou 万安州, Qiongzhou 琼州, Hainan Dao 海南道, Hainan Tebie Xingzhengqu 海南特别行政区, Qiongtai 琼台, Qiongya 琼崖.

Aomen 澳门 (6): Haojing 虴镜, Haojing 濠镜, Haojiang 濠江, Haijing 海镜, Jinghai 镜海, Mage 妈阁.

According to the data presented, one can notice the following:

1. All the provincial administration regions have their own full names, short names and historical names, but only 4 municipalities, 2 special administrative regions and 5 provinces have their stable by-names.

2. A place can have only one full name, while it can have more short names, bynames, and historical names. From Table 1 above, one can also see that the short names of some regions are not limited to one (e.g.: Sichuan, Guizhou), and so do by-names and historical names (e.g.: Beijing, Shanghai).

3. Full names, short names and by-names are related to historical names (cf. Table 1). Most of the full names stem from their historical names. Short names are monosyllabic ones, constructed of one Chinese word and are mostly drawn from historical names (e.g. the short name of Beijing, i.e. Jing 京, comes from historical names such as Beijing 北京, Yanjing 燕京, Jingdu 京都, Jingshi 京师). And the by-names of Hainan Province, such as Qiong- 
tai 琼台 and Qiongya 琼崖, ${ }^{8}$ used in contemporary times, are connected with their historical names.

4. By-names are mainly given to particular places and not to somewhat abstract territories. According to Table 1 for provincial regions, only a few of them have their by-names, but as to particular places, all the places except Taibei have their by-names (cf. Table 2).

5. The term "formal names" seems to be inaccurate when it is used to judge the formality of names. From the perspective of nominatum comprehensiveness, full names are generally considered to be official. However, for the accessibility which names can be used in formal occasions, formal names have never been the only choice. Besides full names, the other three forms of names, i.e. short names, by-names and historical names, are also used in quite formal contexts such as important historical events (e.g.: Songhu huizhan 淞沪 会战 'Battle of Songhu', Songhu 淞沪 being a historical name of Shanghai), governmental news reports (e.g.: Zhongguo gongchandang di shijiuci quanguo daibiao dahui zai Jing bimu 中国共产党第十九次全国代表大会在京 闭幕 'The Communist Party of China's (CPC) 19th National Congress concluded in Beijing', ${ }^{9}$ with Jing 京 a short name of Beijing), titles of official handbooks, tourist guides etc. (e.g., Liuxue Xiang Jiang zhinan 留学香江指 南 'A handbook for overseas students in Xiang Jiang', ${ }^{10}$ Xiang Jiang 香江 being a by-name of Hong Kong).

\subsection{Features and a proposed definition of by-names}

By-names of cities are also metaphorically called chengshi yahao 城市雅号 'laudatory titles of cities' in Chinese. The places with by-names are usually outstanding in terms of their geography, climate, natural resources, economics, politics, culture, etc. Therefore, not all Chinese places have their by-names, but only those which have some distinguishing qualities. Table 2 presents the names of 28 provincial capitals, excluding those of 4 municipalities and 2 special administrative regions already referred to above.

8 The name "Qiongya" refers to the present Hainan province, which is the site of Qiongya Special Committee of the Communist Party of China and Qiongya Revolutionary Base built in 1927.

9 The text comes from China's official website http://cpc.people.com.cn/19th/.

10 The source of the corpus is Wang Feng 汪锋, Wangmen qiuxue ji 王门求学记 [Wang Feng's reminiscences on studying in Wang's School] (Micro-Journal of Linguistics, 2018-05-01), the original text goes: Wo shoudao le Xianggang Chengshi Daxue de luqu tongzhishu, fuyou yiben 《Liuxue Xiang Jiang Zhinan》 我收到了香港城市大学的录取通知书, 附有一本《留学香江指南》 'University of Hongkong City offered me the letter of admission with a brochure of $A$ handbook for Overseas Students in Xiang Jiang'. 
Table 2: The names of 28 provincial capitals

\begin{tabular}{|c|c|c|}
\hline \multicolumn{3}{|c|}{ Provincial Capitals } \\
\hline Official Names & By-Names & Historical Official Names \\
\hline Shijiazhuang 石家庄 & Guoji Zhuang 国际庄 & Shijiazhuang 石家庄 (3) \\
\hline Taiyuan 太原 & Long Cheng 龙城 & Taiyuan 太原 (6) \\
\hline Shenyang 沈阳 & Gongheguo Zhangzi 共和国长子(2) & Shenzhou 沈州 (6) \\
\hline Changchun 长春 & Che Cheng 车城, Beiguo Chuncheng 北国春城 & Changchun 长春 (9) \\
\hline Ha'erbin 哈尔滨 & Bing Cheng 冰城 & Binjiang 滨江 (4) \\
\hline Nanjing 南京 & Liuchao Gudu 六朝古都(8) & Nanjing 南京 (24) \\
\hline Hangzhou 杭州 & Hang Cheng 杭城, Huayuan Cheng 花园城 & Yuhang 余杭 (9) \\
\hline Hefei 合肥 & $\mathrm{Ba} \mathrm{Du}$ 霸都 & Hefei 合淝, Luzhou 庐州 \\
\hline Fuzhou 福州 & Rong Cheng 榕城, Sanshan 三山 & Fuzhou 福州 (14) \\
\hline Nanchang 南昌 & Hong Cheng 洪城, Yingxiong Cheng 英雄城 & Hongzhou 洪州 (4) \\
\hline Jinan 济南 & Quan Cheng 泉城, Li Cheng 历城 & Qizhou 齐州, Lixia 历下(3) \\
\hline Zhengzhou 郑州 & Lü Cheng 绿城, Shang Du 商都 & Xinzheng 新郑 (5) \\
\hline Wuhan 武汉 & Jiang Cheng 江城 & Ezhou 鄂州 (9) \\
\hline Changsha 长沙 & Xing Cheng 星城, Tan Cheng 潭城 & Changsha 长沙 (4) \\
\hline Guangzhou 广州 & Hua Cheng 花城, Yang Cheng 羊城 & Nanyue 南越, Yue 粤 (7) \\
\hline Taibei 台北 & & Taibei 台北 (7) \\
\hline Chengdu 成都 & $\begin{array}{l}\text { Jinguan Cheng 锦官城, Jin Cheng 锦城, } \\
\text { Rong Cheng 蓉城 } \\
\end{array}$ & Chengdu 成都 \\
\hline Guiyang 贵阳 & Lin Cheng 林城, Zhu Cheng 筑城 & Guiyan 贵阳 (8) \\
\hline Kunming 昆明 & $\begin{array}{l}\text { Chun Cheng 春城, Hua Cheng 花城 } \\
\end{array}$ & Kunming 昆明 (2) \\
\hline Xi'an 西安 & $\begin{array}{l}\text { Gu Cheng 古城, Tang Cheng 唐城, } \\
\text { Han Cheng 汉城 }\end{array}$ & Chang'an 长安 (10) \\
\hline Lanzhou 兰州 & Guaguo Cheng 瓜果城 & Lanzhou 兰州 (2) \\
\hline Xining 西宁 & Xia Du 夏都 & Xining 西宁 (7) \\
\hline Haikou 海口 & Ye Cheng 椰城 & Qiongzhou 琼州 \\
\hline Huhehaote $^{11}$ 呼河浩特 & Qing Cheng 青城 & Huhehaote 呼和浩特 (8) \\
\hline Nanning 南宁 & Yong Cheng 邑城, Wuxiang Cheng 五象城(4) & Nanning 南宁 (3) \\
\hline Lasa 拉萨 & Riguang Cheng 日光城 & Lasa 拉萨 (3) \\
\hline Yinchuan 银川 & Fenghuang Cheng 凤凰城 & Yinchuan 银川 (9) \\
\hline Wulumuqi 乌鲁木齐 & Niao Shi 鸟市 & Wulumuqi 乌鲁木齐 (4) \\
\hline
\end{tabular}

The data in Table 2 show that almost every provincial capital except Taibei has at least one by-name. The capitals with more by-names seem to represent

${ }^{11}$ According to Article 6.2.3 of "Basic Rules of the Chinese Phonetic Alphabet Orthography", Pinyin forms of Chinese place names, which come from other languages, such as "Hohhot", "Lhasa" and "Ürümqi”" etc., should be written in Chinese Pinyin as "Huhehaote 呼和浩特”, "Lasa 拉萨” and “Wulumuqi 乌鲁木齐” respectively. 
something like the Matthew effect: ${ }^{12}$ more distinguished places will attract more concern and affection. And, in fact, besides the by-names of provincial capitals, most by-names are bestowed upon medium and small-sized towns, where inhabitants live harmoniously and feel self-esteem in their daily life, e.g.: Weifang 潍 坊 in Shandong province is called Fengzheng Cheng 风笔城 'Kite Town'; Jingdezhen 景德镇 in Jiangxi province is called Ci Du 瓷都 “Chinaware Metropolis'.

In some expressions where writers/speakers intend to demonstrate their elegant, poetic taste in a quaint and old-fashioned way, historical names are also used as by-names in contemporary texts, e.g.: the name Jinguan Cheng 锦官城 'Jinguan City', one of Chengdu's historical names, appears in the poem "Cong Jinguan Cheng de citang zhuying, dao Qing Cheng woye de guaguo piaoxiang 从锦官城外的祠堂竹影, 到青城沃野的瓜果飘香 'From the bamboo shadow of ancestral temples outside Jinguan City, to the fruits fragrance in fertile fields of Qing City"' (News report of Xinhua News Agency, Aug. 2004).

Therefore, the suggested definition of Chinese by-names of places is as follows: "honorific names bestowed on special places of abundant resources, having more close connections with local economics, cultural interests, daily life of people and aiming at highlighting and lauding the distinguished features of places". This definition is preferable to the former one, which described by-names as rare and informal place names.

\section{STRUCTURAL FEATURES OF BY-NAMES}

By-names are generally composed of two syllables (two morphemes or words) and only a few of them are made of three or more syllables. No matter how many syllables the by-names have, they are mainly constructed of two parts, i.e. a specific part and a generic part.

\subsection{Adjective morpheme + noun morpheme}

Some contemporary by-names are made by combining adjectives and nouns into new noun phrases. The functions of adjective parts are descriptive, whereas noun parts are generic, e.g.:

The by-name of Chengde 承德 in Hebei Province is Re He 热河 'Hot River', because a river called Wulie He 武烈河 runs through almost the whole town

12 The Matthew effect, a term used by sociologists and economists, reflects a social phenomenon of polarization, of the rich getting richer and the poor getting poorer. The name comes from a fable in the Bible that says "For unto every one that hath shall be given and he shall have abundance, but from him that hath not shall be taken away even that which he hath" (Matthew XXV:29, King James Version). 
and thus, even in severe cold winters, its thermal water never freezes and the hot vapour is suspended in the cold air.

Tian Cheng 甜城 'Sweet Town' is a by-name of Neijiang 内江 in Sichuan Province. The town abounds in high quality sugarcane, sweets and preserved fruit.

Jiaxing 嘉兴 in Zhejiang province has the by-name Xiu Cheng 秀城 'Talented Town', because its scenic river with colourful water legendarily brought fortune to the scholars who saw it.

Xiang Jiang 香江 'Fragrant River' is a by-name of Xianggang 香港 'Hongkong (lit. Fragrant Harbour)'. It is said that approximately in the Ming Dynasty (1368-1662) several ships delivering herbs and spices docked in the port where a stream ran close by, and gradually the stream smelt spicy due to the aroma permeating the air.

The terms re 热 'hot', tian 甜 'sweet', xiu 秀 'talented' and xiang 香 'fragrant' in the above by-names are adjective morphemes which modify and describe the generic noun morpheme.

\subsection{Noun morpheme + directional morpheme}

As it has been said in the above section, some historical by-names were not only used in the past, but remain in use today.

Lixia 历下 is the historical by-name of Jinan 济南 in Shandong province. It is said that the legendary ancient emperor, Da Shun 大舜 'Great Shun' (c. XXII century B.C.), stayed at the foot of Li Shan 历山 'Li Mountain', where Jinan 济 南 was later located, so Jinan 济南 is also called Lixia 历下 'Below Li Mountain', where $L i$ 历refers to Li Shan 历山 'Li Mountain' and xia 下 'below' is a directional indicator.

Baixia 白下 is one of the by-names of Nanjing 南京. Its history can be traced back 1,500 years. The city god was located at the foot of Baishi Shan 白石山 'White Stone Hill' in Nanjing and later the first term bai 白 of the hill name was kept and combined with the directional term xia 下 'below' to indicate Nanjing 南京.

Shanghai 上海 is called Hu 沪 or Hushang 沪上 because local fishermen invented a fishing tool called $h u$ 沪/滬 'bamboo trap for fish'. Because the area where " $h u$ 扈" was originally produced is located at the mouth of the Yangtze River, and its altitude is above the sea level, so the by-name of Hushang 沪上 'Above Hu' has come into being.

In Chinese spatial cognition, the orientations of qian/hou/zuo/you 前/后/左/右 'front/back/left/right' correspond to the directions of bei/nan/dong/xi 北/南/东/西 'north/south/east/west'. In the Song Dynasty (960-1279), the Eastern Road and the Western Road of Huainan were set in 
Jianghuai 江淮. Yangzhou 扬州 was situated on the Eastern Road of Huainan and is therefore called Huaizuo 淮左 'Left of Huai'. And another by-name of Yangzhou 扬州 is Zhuxi 竹西 'West of Zhu' because there was a lovely pavilion called Zhu竹 to the east of Yangzhou 扬州.

Actually, besides by-names, quite a few provincial full names and capital official names also keep inherited morphological combinations of nouns and directional terms, e.g.: Hubei 湖北, Hunan 湖南, Hebei 河北, Henan 河南, Hainan 海南, Yunnan 云南, Jiangxi 江西, Guangdong 广东, Guangxi 广西, Shandong 山东, Shanxi 山西, Taibei 台北, or Tainan 台南.

\subsection{Noun morpheme + noun morpheme}

Apart from the above two combinations, combining two nouns to form a place name is very common in Chinese (Han, 1991; Shao, 2004). According to the research into place names recorded in "Shuijing Zhu 水经注 [Notes on Waterways]", conducted by Li Daoyuan in the Northern Wei Dynasty (317-533), there were over 2,400 nominal terms altogether. They were classified into 24 categories, such as e.g. human, relic, state, tribe, dialect, animal, plant, mineral, topography, soil, climate, colour, sound, direction, shape, number, myth, legend, etc. (Chen, 2012).

The majority of Chinese by-names are just combinations of two nominal elements. The structural relationship between two nouns is that the first morpheme/word usually modifies and determines the second one, e.g.: Yin $\mathrm{Du}$ 殷 都 ‘Capital of Shang Dynasty', Bao Dao 宝岛 'Island of Treasures'. The first morpheme/word yin 殷 ‘Shang Dynasty’, bao 宝 ‘treasure’ describes the second one, $d u$ 都 'capital' and $d a o$ 岛 'island', being the generic constituents of bynames. There are numerous examples of these types of noun-noun compounds.

\subsection{Chinese four-syllable by-names}

Apart from the above described compound by-names made of two morphemes (i.e. two syllables), some by-names are composed of four syllables, e.g.:

\begin{tabular}{|l|l|}
\hline \multicolumn{1}{|c|}{ Official Names } & \multicolumn{1}{c|}{ By-Names } \\
\hline Hubei 湖北 & Qianhu zhi Sheng 千湖之省 'Province of Thousands of Lakes’; \\
\hline Sichuan四川 & Tianfu zhi Guo 天府之国 ‘Land of Abundance'; \\
\hline Changzhou 常州 & Yumi zhi Xiang 鱼米之乡 'Land of Fish and Rice’; \\
\hline Xiamen 厦门 & Yinyue zhi Dao 音乐之岛 'Music Island’; \\
\hline Nanjing 南京 & $\begin{array}{l}\text { Bo'ai zhi Du 博爱之都 ‘Philanthropic Capital', Kaiming zhi Cheng 开明之城 } \\
\text { 'Enlightened City'. }\end{array}$ \\
\hline
\end{tabular}


By-names with four syllables generally contain zhi 之 between modifying parts and generic parts. $Z h i$ 之 is a functional word, indicating that the first parts are determiners or qualifiers of the second ones in a grammatical relation.

\section{SEMANTIC FEATURES OF BY-NAMES}

For thousands of years there has been a traditional Chinese cultural concept of "tianren heyi 天人合一 "coexistence of human and nature""13 to express the idea that universe and human beings get along well with each other. According to an old Chinese saying, “Renzhe yao shan, zhizhe yao shui 仁者乐山, 智者乐水 "The benevolent loves mountains while the wise loves rivers", i.e. people with lofty ideals love to manifest their noble virtue and social value via mountains and rivers of natural lands. The value of respecting and even worshiping the nature is reflected in some by-names of places. For Chinese, all things on earth that inspire pleasant, lofty and laudatory emotions, including animals, plants, mountains, rivers, climate, unique topography, natural minerals, manufactured products, prominent figures etc., could be inspirations for the creation of good by-names.

The second parts of by-names are mostly generic topographic terms, such as cheng 城 'town/city', $d u$ 都 'capital/metropolis', jiang 江 'river', shan 山 'mountain', dao 岛 'island', xiang 乡 'village', zhou 洲 'continent', guo 国 'country/land', among which the proportion of cheng 城 'city/town' ${ }^{14}$ accounts for over $96 \%$. The meaning of generic parts will not be discussed further and only the specific parts of by-names will be presented below.

\subsection{By-names referring to real and mythical animals}

The examples of specific by-name components equal to animal names are:

\begin{tabular}{|l|l|l|}
\hline \multicolumn{1}{|c|}{ Animals } & \multicolumn{1}{c|}{ By-Names } & \multicolumn{1}{c|}{ Official Names } \\
\hline yang 羊 ‘sheep’ & Yang Cheng 羊城 ‘Sheep City’ & Guangzhou 广州 \\
\hline li 鲤 ‘carp’ & Li Cheng 鲤城 ‘Carp Town’ & Quanzhou 泉州 \\
\hline jiu 鸠 'turtledove’ & Jiu Jiang 鸠江 ‘Turtledove River’ & Wuhu 芜湖 \\
\hline
\end{tabular}

13 The conception of the "coexistence of human and nature" stems from Zhuangzi, a Taoist thinker (about $369-286$ B.C.), and later developed into a philosophical system of "unity of man and nature". The thought stresses on the fact that man and nature are interlinked in essence, and all human's activities should conform to the laws of nature to achieve harmony between man and nature.

${ }^{14}$ The scale and coverage of cheng 城 'city/town' is much larger than that of zhen 镇 'town', but by-names of Chinese places do not consistently distinguish between the two terms. 


\begin{tabular}{|c|c|c|}
\hline Animals & By-Names & Official Names \\
\hline \multirow{2}{*}{ e 鹅 'goose' } & \multirow{2}{*}{ E Cheng 鹅城 'Goose Town’ } & Baise 百色 \\
\hline & & Huizhou 惠州 \\
\hline ying 鹰 'eagle' & Ying Cheng 鹰城 ‘Eagle Town’ & Pingdingshan 平顶山 \\
\hline \multirow{2}{*}{ lu 鹿‘deer’ } & \multirow{2}{*}{ Lu Cheng 鹿城 ‘Deer Town' } & Wenzhou 温州 \\
\hline & & Baotou 包头 \\
\hline he 鹤 'crane' & He Cheng 鹤城 ‘Crane City’ & Qiqiha'er 齐齐哈尔 \\
\hline peng 鹏 myth. 'roc' & Peng Cheng 鹏城 'Roc City' & Shenzhen 深圳 \\
\hline $\begin{array}{l}\text { fenghuang 凤凰 myth. } \\
\text { 'phoenix' }\end{array}$ & Fenghuang Cheng 凤凰城 'Phoenix Town’ & Liaocheng 聊城 \\
\hline feng 凤 myth. 'phoenix' & Feng Cheng 凤城 'Phoenix Town' & Chaozhou 潮州 \\
\hline yan 雁 'wild goose' & Yan Cheng 雁城 'Wild Goose Town’ & Hengyang 衡阳 \\
\hline long 龙 ‘dinosaur' & Long Cheng 龙城 'Dinosaur Town' & Puyang 誉阳 \\
\hline \multirow{3}{*}{ long 龙 myth.'dragon’ } & \multirow{3}{*}{ Long Cheng 龙城 ‘Dragon City’ } & Taiyuan 太原 \\
\hline & & Changzhou 常州 \\
\hline & & Liuzhou 柳州 \\
\hline shi 狮 'lion’ & Shi Cheng 狮城 ‘Lion Town’ & Cangzhou 沧州 \\
\hline hu 虎 'tiger' & Hu Cheng 虎城 ‘Tiger Town’ & Zunyi 遵义 \\
\hline \begin{tabular}{|l} 
qilin 麒麟 myth.'kylin’, \\
'(Chinese) unicorn’
\end{tabular} & Qilin Cheng 麒麟城 ‘Kylin Town’ & Qujing 曲靖 \\
\hline lu 鹭 'egret' & 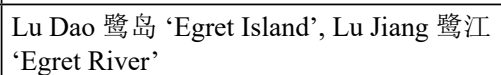 & Xiamen 厦门 \\
\hline
\end{tabular}

Animal names are often used in by-names, and sometimes one animal name is used in several onyms. The reasons for using particular animal names to create by-names are as follows.

1. The animals mentioned in by-names really live or lived in the area. e.g.: Qiqiha'er 齐齐哈尔 is called Crane City because it is the hometown of redcrowned cranes that inhabit the nearby Zalong Natural Reserve. Baotou 包 头 is a city with the largest green area in the Inner Mongolia Autonomous Region, with numerous wild deer inhabiting peripheral grassland. The meaning of Baotou 包头 in the Mongolian language is just 'a place with deer', so Baotou 包头 is called Deer Town. Wuhu 芜湖 is called Turtledove River because in ancient times the place was a low-lying area covered with lakes, a habitat of algae and turtledoves. Dinosaur Town, the by-name of Puyang 泆阳, comes from the fact that the fossils of a clamshell dinosaur in ancient tombs of the Yangshao culture (5,000 B.C. $-3,000$ B.C.) was excavated in 1987 in this place, and therefore it was called the first dinosaur in China. Hengyang 衡阳 is called Wild Goose Town because the town is situated in the south of the Hen Mountain, and annually migrating birds/wild geese have a rest stop there. 
2. Territorial outlines are similar to the shapes of related animals, e.g.: Quanzhou 泉州 is called Carp Town because the city outline is just like the shape of a carp. The outline of Baise 百色 on the map resembles a flying goose, so its by-name is Goose Town. There are three various explanations for Liuzhou 柳州 as Dragon Town: the first one is that Liu Jiang 柳江 'Liu River' looks like a huge dragon winding along the city; the second one comes from a legend saying that eight dragons appeared in Liu River in 540 B.C. and since then Liu River has also been called Long Jiang 龙江 'Dragon River'; the third explanation attributes the name to the historical name of Longcheng Jun 龙城郡 ‘Dragon Town County' in about 634 of the Tang Dynasty and about $1082-1125$ of the Northern Song Dynasty.

3. Important historical events are related to some animal totems, e.g.: Taiyuan 太原 is called Dragon City, 龙城, because it was the birthplace of several emperors and the capital in the time of the Five Dynasties and Ten Kingdoms (907-979), and an emperor in ancient China was generally deified as a powerful dragon. Chaozhou 潮州 is called Phoenix Town 凤城; the name is connected with Phoenix Hill situated in this place, the name already recorded before the time of the Song Dynasty (960-1127), and directly originates from its historical by-name Phoenix Town. Pingdingshan 平顶山 is called Eagle Town 鹰城, because it was located in a feudal state named Ying Guo 应国 'Ying State' in 1046-700 B.C., ying 鹰 'eagle' was the totem of this state, and what is more, ying 应 and ying 鹰 have a similar Chinese pronunciation, so for the by-name of this city ying 鹰 'eagle' was later selected, and not ying 应.

4. Local legends are related to the mythological animals symbolizing auspiciousness, e.g.: the by-name Sheep City of Guangzhou 广州 comes from the legend of Wuyang xian gu, cui yu Chuting 五羊衔谷, 萃于楚庭 'five immortal sheep with rice stalks in their mouth, a distinguished gathering and blessing on Chuting (i.e. Gangzhou)', recorded in the Zhou Dynasty about 2,500 years ago. The legend of Deer Town for Wenzhou 温州 comes from Wenzhoufu Zhi 温州府 志 'Wenzhou Chronicle', which describes a fairy deer that ran through the city with a flower in its mouth when the governor Xie Jin 谢晋 built fortifications there in 323. The by-name Kylin Town for Qujing 曲靖 is derived from the story that in ancient times a fairy riding a kylin (Chinese mythical unicorn) made a torrential rain stop the severe drought in this area, and the people rescued from the disaster called this place Kylin Town to commemorate the spirit beast.

5. Banter ${ }^{15}$ related to some kinds of animals amuse people, e.g.: Ürümqi in Xinjiang has been derided as Niao Shi 鸟市 'Bird City' since 1983. A vermicelli

15 The term banter in this paper means a friendly conversation in which people make a lot of jokes and amusing remarks. 
manufactory in Ürümqi imported from Japan a batch of bags with the name Wulumuqi 乌鲁木齐 'Ürümqi' printed on them. The mistake, i.e. the first character $w u$ 乌 was mis-printed as niao 乌 'a bird', was not discovered until the bulk cargo had arrived in Ürümqi, thus the mis-added dot to 乌 resulted in the city's by-name 'Bird City'.

\subsection{By-names referring to plants}

Quite a few by-names come from varieties of plants or parts of plants, e.g.:

\begin{tabular}{|c|c|c|}
\hline Plants & By-Names & Official Names \\
\hline he 禾 'millet' & He Cheng 禾城 'Millet Town' & Jiaxing 嘉兴 \\
\hline hui 穗 'rice spike' & Hui Cheng 穗城 ‘Rice Spike City’ & Guangzhou 广州 \\
\hline rong 榕 ‘banian’ & Rong Cheng 榕城 ‘Banian City’ & Fuzhou 福州 \\
\hline rong 蓉 'hibiscus' & Rong Cheng 蓉城 ‘Hibiscus City’ & Chengdu 成都 \\
\hline li 荔 'litchi' & Li Cheng 荔城 ‘Litchi Town’ & Putian 莆田 \\
\hline ke 柯 'stalk' & Ke Cheng 柯城 'Stalk Town' & Quzhou 槜州 \\
\hline citong 刺桐 'erythrina' & Citong Cheng 刺桐城 'Erythrina Town' & Quanzhou 泉州 \\
\hline mudan 牡丹 'peony' & Mudan Cheng 牡丹城 ‘Peony Town’ & Luoyang 洛阳 \\
\hline liu 柳 'willow' & Liu Cheng 柳城 'Willow Town’ & Changde 常德 \\
\hline \multirow{3}{*}{ lian 莲 'lotus' } & \multirow{3}{*}{ Lian Cheng 莲城 'Lotus Town’ } & Xiangtan 湘潭 \\
\hline & & Lishui 丽水 \\
\hline & & Xuchang 许昌 \\
\hline
\end{tabular}

The above places without exception abound in plants or crops corresponding with their by-names. Chinese appreciate the plants closely associated with their daily life, therefore many official names are also connected with plants, e.g.:

\begin{tabular}{|c|c|}
\hline Plants & Official Names \\
\hline mei 梅 'plum' & Mei Ling 梅岭 'Plum Mountain’; \\
\hline gu 谷 ‘grain’ & Gu Cheng 谷城 ‘Grain Town’; \\
\hline lianhua 莲花 'lotus' & Lianhua Shan 莲花山 'Lotus Hill’; \\
\hline mudan 牡丹 'peony' & Mudan Jiang 牡丹江 'Peony River'; \\
\hline zao 杳 ‘jujube’ & Zao Zhuang 菄庄 'Jujube Village'; \\
\hline ma 麻 'hemp' & Ma Cheng 麻城 ‘Hemp Town’; \\
\hline ou 藕 'lotus root' & Ou Chi 藕池 'Lotus Root Pond'. \\
\hline
\end{tabular}

The examples like these are too many to enumerate, cf. (Chen, 1985; Kałużyńska, 2002; Sun, 2010). 


\subsection{By-names referring to minerals}

The places whose by-names contain some kind of mineral terms are generally prominent industrial centers or places abundant in mineral resources, e.g.:

\begin{tabular}{|c|c|c|}
\hline Minerals & By-Names & Official Names \\
\hline meng 锰 'manganese' & Meng Du 锰都 'Manganese Capital' & Xiangtan 湘潭 \\
\hline xi 锡 ‘tin' & Xi Du 锡都 'Tin Capital' & Gejiu 个旧 \\
\hline Shiyou石油 'petroleum' & Shiyou Cheng 石油城 'Petroleum Town' & Yumeng 玉门 \\
\hline ti 锑 'stibium' & Ti Du 锑都 'Stibium Capital' & Lengshuijiang 冷水江 \\
\hline nie 镍 'nickel' & Nie Du 镍都 'Nickel Capital' & Jinchang 金昌 \\
\hline mei 煤 ‘coal’ & Mei Du 煤都 'Coal Capital’ & Fushun 抚顺 \\
\hline \multirow{2}{*}{ you 油'oil’ } & \multirow{2}{*}{ You Cheng 油城‘Oil Town’ } & Daqing 大庆 \\
\hline & & Dongying 东营 \\
\hline yan 盐 'salt' & $\begin{array}{l}\text { Yan Du 盐都 'Salt Capital'/ Yan Cheng 盐城 } \\
\text { 'Salt Town' }\end{array}$ & Zigong 自贡 \\
\hline \multirow[t]{2}{*}{ gang 钢 'steel' } & $\begin{array}{l}\text { Gang Du 钢都 'Steel Capital'/ Gang Cheng 钢城 } \\
\text { 'Steel Town' }\end{array}$ & Anshan 鞍山 \\
\hline & $\begin{array}{l}\text { Caoyuan Gangcheng 草原钢城 'Steel Town In } \\
\text { Prairie' }\end{array}$ & Baotou 包头 \\
\hline
\end{tabular}

\subsection{By-names referring to locally manufactured products}

Some places are named for their locally manufactured products. The following are only representatives of the numerous by-names of this kind:

\begin{tabular}{|c|c|c|}
\hline Products & By-Names & Official Names \\
\hline cha 茶 'tea' & Cha Xiang 茶乡 'Tea Hometown' & Anxi 安溪 \\
\hline \multirow{4}{*}{ yao 药 'herbal medicine' } & \multirow{4}{*}{ Yao Du 药都 'Herbal Medicine Capital' } & Bozhou 毫州 \\
\hline & & Zhangshu 樟树 \\
\hline & & Yuzhou 禹州 \\
\hline & & Anguo 安国 \\
\hline \multirow[t]{2}{*}{ ci 瓷 'chinaware' } & Ci Du 瓷都 'Chinaware Metropolis’ & Jingdezhen 景德镇 \\
\hline & Ci Du 瓷都 ‘Chinaware Capital’ & Chaozhou 潮州 \\
\hline jin 锦 'brocade' & Jin Cheng 锦城 'Brocade City’ & Chengdu 成都 \\
\hline \multirow[t]{2}{*}{ jiu 酒 ‘wine’ } & Jiu Cheng 酒城 'Wine Town' & Luzhou 泸州 \\
\hline & Jiu Xiang 酒乡 'Wine Hometown' & Zunyi 遵义 \\
\hline \multirow[t]{2}{*}{ che 车 'automobile' } & Che Cheng 车城 'Automobile City' & Changchun 长春 \\
\hline & Che Cheng 车城 'Automobile Town' & Shiyan 十堰 \\
\hline
\end{tabular}




\begin{tabular}{|c|c|c|}
\hline Products & By-Names & Official Names \\
\hline fuzhuang 服装 'clothes' & Fuzhuang Cheng 服装城 ‘Clothes Town’ & Shishi 石狮 \\
\hline fangzhi 纺织 'textile' & Fangzhi Cheng 纺织城 'Textile Town' & Xianyang 咸阳 \\
\hline fengzheng 风筝 'kite' & Fengzheng Cheng 风筝城 'Kite Town’ & Weifang 潍坊 \\
\hline tao 陶 'pottery' & Tao Du 陶都 ‘Pottery Capital’ & Yixing 宜兴 \\
\hline zhu 珠 'pearl' & Zhu Cheng 珠城 'Pearl Town' & Zhucheng 珠城 \\
\hline yan 烟 'tobacco' & Yan Cheng 烟城 ‘Tobacco Town’ & Xuchang 许昌 \\
\hline tang 糖 'sugar' & Tang Xiang 糖乡 'Sugar Town’ & Yiwu 义乌 \\
\hline shipin 食品 'processed food' & Shipin Cheng 食品城 'Processed Food Town' & Luohe 漯河 \\
\hline
\end{tabular}

\subsection{By-names referring to climate}

Some by-names are attributed to local unique temperature, weather or natural scenery, e.g.:

1. Temperature. The annual average temperature in Kunming 昆明 is $16.5^{\circ} \mathrm{C}$, which makes people feel like in spring all the year round, while Xining 西 宁 in Qinghai province is just like a cozy summer resort when all the country experiences the scorching heat in summer, therefore the by-names of the two places are respectively Chun Cheng 春城 ‘Spring Town' and Xia Du 夏 都 'Summer Resort'.

2. Weather. Due to the local climate, it is rainy for over 200 days a year in Ya'an 雅安 of Sichuan province, therefore it is called Yu Cheng 雨城 'Rainy Town'; Chongqing 重庆 is surrounded by mountains and the moisture evaporated into the air cannot spread outside, which contributes to its foggy conditions, so Wu Du 雾都 'Foggy Capital' is a by-name of Chongqing; Lasa 拉 萨 'Lhasa' in Tibet has the strong sunlight and its by-name is Riguang Cheng 日光城 'Sunlight City'.

3. Natural scenery. Ha'erbin 哈尔滨 'Harbin' is called Bing Cheng 冰城 'Ice City' because it is a beautiful ice and snow world in winter and Harbin International Ice and Snow Festival is held there. The by-name Huo Zhou 火洲 'Flame Continent' of Tulufan 吐鲁番 in Xinjiang comes from two reasons: one reason is its very high temperature in summer and the other one is just the nearby location of "Flame Mountain" of the well-known novel "Xiyou Ji 西游记 [Pilgrimage to the West]" (Wu, 1995). The by-name of Xichang 西 昌 is Yue Cheng 月城 'Moon City', because the lake called Deng Hai 邓海 located in this area has been considered since 130 B.C. to be one of the best places to watch the moon. 


\subsection{By-names referring to geographical location}

Some places are situated at or by particular natural geographical features, such as mountains, rivers, lakes, islands, seashore etc., so their by-names are related to these landforms, e.g.:

The folk name of Wuhan 武汉 is Jiang Cheng 江城 'River City', because it is located at the junction of the Yangtze River and the Han River;

Suzhou 苏州 is called Shui Cheng 水城 'Water Town' for a multitude of crisscrossing waterways in the town;

Jinan 济南 is called Quan Cheng 泉城 'Spring City' for abundant hot springs covering the city;

Chongqing 重庆 is named Shan Cheng 山城 'Mountain City', because it is surrounded by mountains;

Zhoushan 舟山 is called Dao Cheng 岛城 'Island Town', because it is located in the Zhoushan Archipelago;

Qingdao 青岛 is also called Dao Cheng 岛城 'Island City', because it is located in the south of the Shandong Peninsula;

Dalian 大连 is called Bincheng 滨城 'Seashore City', because of its very long coastline.

\subsection{By-names referring to humans}

Human society is also a source of by-names of various types. For example:

Nanchang 南昌 is called Yingxiong Cheng 英雄城 'Hero City', because the Communist Party of China organized there the first armed force and staged the first uprising in 1927;

Beijing is called Huang Cheng 皇城 'Imperial City', because it was the capital of six dynasties and many emperors in the history of China;

The by-name Li Cheng 蟙城 of Shaoxing 绍兴 comes from the given name of a rich merchant Fan Li范蛍, who built the city about 2,000 years ago;

Qufu 曲阜 is called Sheng Cheng 圣城 'Sage City', because it is the hometown of Confucius (551-479 B.C.);

Foshan 佛山 is called Shan Cheng 禅城 'Buddhist City', because a monk from Kashmir built a temple there and started to spread Buddhism in 298;

Gui Cheng 鬼城 ‘Ghost Town' is a by-name of Fengdu 酆都, well-known for its unique ghost culture;

Ba Du 霸都 'Bully Capital' is a teasing expression that people use online with Hefei 合肥, because of the funny, shocking image that the two Chinese terms evoke. The second term fei 肥 means 'fat' in modern Chinese and the first 
term he 合 means 'two people together'. It's not difficult to imagine a towering giant body.

\subsection{By-names referring to areas}

The by-names of three or more syllables should also be regarded as combinations of two semantic parts, but the second components with generic referents have different semantic features, e.g.:

\begin{tabular}{|l|l|}
\hline \multicolumn{2}{|c|}{ Oroup A } \\
\hline \multicolumn{1}{|c|}{ Official Names } & \multicolumn{1}{c|}{ By-Names } \\
\hline Shijiazhuang 石家庄 & Guoji Zhuang 国际庄 ‘International Village'; \\
\hline Sichuan 四川 & Tianfu zhi Guo 天府之国 ‘Land of Heaven'. \\
\hline
\end{tabular}

\begin{tabular}{|l|l|}
\hline \multicolumn{2}{|c|}{ Oroup B } \\
\hline \multicolumn{1}{|c|}{ Official Names } & \multicolumn{1}{c|}{ By-Names } \\
\hline Shanghai 上海 & Dongfang Mingzhu 东方明珠 ‘Oriental Pearl’; \\
\hline Tianjin 天津 & Bohai Mingzhu 渤海明珠 ‘Bohai Pearl’; \\
\hline Shenyang 沈阳 & Gongheguo Zhangzi 共和国长子 'Republic's Eldest Son’. \\
\hline
\end{tabular}

\begin{tabular}{|l|l|}
\hline \multicolumn{2}{|c|}{ Group C } \\
\hline \multicolumn{1}{|c|}{ Official Names } & \multicolumn{1}{c|}{ By-Names } \\
\hline Shanghai 上海 & Dongfang Bali 东方巴黎 ‘Oriental Paris'; \\
\hline Shenyang 沈阳 & Dongfang Lu'er 东方鲁尔 ‘Oriental Ruhr’; \\
\hline Suzhou 苏州 & Dongfang Weinisi 东方威尼斯 ‘Oriental Venice’. \\
\hline
\end{tabular}

The first components of by-names in the above 3 groups, such as guoji 国际 'international', tianfu 天府 'heaven', dongfang 东方 'orient/ eastern', Bohai 浡 海 'Bo Sea' and gongheguo 共和国 'republic' are the area determiners, but the second parts are different: zhuang 庄 'village', guo 国 'land', 'country' of the by-names in Group A are generic referents, mingzhu 明珠 'pearl', zhangzi 长 子 'eldest son' in Group B are metaphoric referents, whereas "Paris", "Ruhr", "Venice" in Group C are borrowed names of specific foreign places.

\section{CONCLUSIONS}

From the perspective of language use, place names can be divided into full names, official names, short names, historical names, by-names etc. Chinese by-names of places are not equivalent to informal names and they are not in opposition to non-common names or formal names. They have been generally be- 
stowed on particular places winning people's affection. By-names can be considered as "honorific names bestowed to special places of abundant resources, having more close connections with local economics, cultural interests, daily life of people and aiming at highlighting and lauding the distinguished features of places". Chinese by-names are mainly composed of two parts, i.e. a specific part and a generic part. They are mostly constructed of two syllables (morphemes) and occasionally of more syllables (morphemes), usually three or four. The lexical meanings of lexical items forming specific parts of by-names mainly refer to natural objects, such as mountains, rivers, plants, animals, minerals etc. Contemporary by-names vary in frequency and stability. The paper is a basic study on these by-names that have a high frequency, stability and acceptability in China.

\section{SELECTED REFERENCES}

Chen, M. 陈梦家 (1965). Yinxu buci zongshu 殷墟卜辞综述 [Review of Oracle Inscriptions]. Beijing: Kexue chubanshe.

Chen, Q. 陈桥驿 (1981). Lun Dimingxue jiqi fazhan 论地名学及其发展 [Toponomastics and Its Development]. Zhongguo lishi dili luncong 中国历史地理论丛 [China Historical Geography Symposia]. Vol.1.

Chen, Q. 陈桥驿 (2012). “Shuijingzhu” diming huibian “水经注” 地名汇编 [The Collection of Place Names in "Notes on Waterways"]". Beijing: Zhonghua shuju.

Han, G. 韩光辉 (1991). Zhongguo dimingxue de diming yuanyuan he diming yange de yanjiu 中国地名学的地名渊源和地名沿革的研究 [Study on the Origin and Development of Chinese Toponymy], Zhongguo lishi dili luncong 中国历史地理论从 [China Historical Geography Symposia]. Vol. 4, pp. 241-251.

HDC (2011). Hanyu Da Cidian 汉语大词典 [Great Chinese Dictionary]. Shanghai: Shanghai cishu chubanshe.

Kałużyńska, I. (2002). Contemporary Chinese Place Names. Names of Administrative Divisions at County and City Level. Bern, Berlin, Bruxelles, Frankfurt am Main, New York, Oxford, Wien: Peter Lang AG, European Academic Publishers.

Needham, J. (1959). Science and Civilisation in China. Cambridge: Cambridge University Press. Vol. 3.

Niu, R. 牛汝辰 (2016). Zhongguo diming zhanggu cidian 中国地名掌故词典 [Dictionary of Anecdotes on Chinese Place Names]. Beijing: Zhongguo shehui chubanshe.

Playfair, G.M.H. (1910). The Cities and Towns of China. A Geographical Dictionary. Hongkong, Yokohama, Singapore: Kelly \& Walsh Ltd.

Richard, L. (1908). Comprehensive Geography of the Chinese Empire. Shanghai: T'usewei Press.

Shao, M. 郡明武 (2004). Zhongguo diming laili leishuo 中国地名来历类说 [The Origin of Chinese Place Names]. Zhongguo difangzhi 中国地方志 [Chinese Local Chronicles]. Vol. 12.

Shi, D. 史定国 (1994). Woguo diming pinxie guoji biaozhunhua wenti 我国地名拼写国际标准化 问题 [International Standardization on Spelling Chinese Place Names]. Yuyan weizi yingyong 语言文字应用 [Applied linguistics]. Vol. 4.

Shi, W. 史为乐 (2017). Zhongguo lishi diming da cidian — zengdingben 中国历史地名大辞典一 增订本 [Chinese Historical Place Names Dictionary (revised edition)]. Beijing: Zhongguo shehui kexue chubanshe. 
Spencer, J.E. (1941). Chinese Place Names and the Appreciation of Geographic Realities. Geographer Review. 31, pp. 79-94.

Sun, Y. 孙元巩 (2010). Zhongguo diming youlai chutan 中国地名由来初探 [Study on the Origin of Chinese Place Names]. Zhongguo diming 中国地名 [Chinese Place Names]. Vol. 8, pp. $20-22$.

Wang, D. 王大学 (2016). Guoji xuejie guojia lishi dili xinxi xitong jianshe yu liyong de xianzhuang ji qishi 国际学界国家历史地理信息系统建设与利用的现状及启示 [The Status Quo and Tendency of NHGIS in International Academia]. Jiangsu shifan daxue xuebao (Zhexue shehui kexue ban) 江苏师范大学学报 (哲学社会科学版) [Journal of Jiangsu Normal University (Philosophy and Social Sciences Edition)]. Vol. 3, pp. 98-104.

Wang, F. 汪锋 (2018). Wangmen qiuxue ji 王门求学记 [Wang Feng's Reminiscences on Studying in Wang's School], Micro-journal of Linguistics. 2018-05-01.

Wang, J. 王际桐 (2015). Zhongguo diming hanzi shuxie ji duyin de guifan 中国地名汉字书写及 读音的规范 [The Standard on Chinese Character Writing and Pronunciation of Chinese Place Names]. Zhongguo diming中国地名 [Chinese Place Names]. Vol. 12, pp. 54-55.

Wu, Ch. 吴成恩 (Ming Dynasty, 1995 ed.). Xiyou Ji 西游记 [Pilgrimage to the West]. Shanghai: Shanghai Guji Chubanshe.

XHC (2016). Xiandai Hanyu Cidian 现代汉语词典 [Modern Chinese Dictionary]. Beijing: Shangwu yinshuguan.

Zhonghua Renmin Gongheguo Guojia Biaozhun: Hanyu Pinyin Zhengcifa Jiben Guize 中华人民 共和国国家标准·汉语拼音正词法基本规则 [Basic Rules of the Chinese Phonetic Alphabet Orthography of the National Standard of the People's Republic of China], code: GB/T161592012.

Zhonghua Renmin Gongheguo Xingzheng Quhua Jiance 中华人民共和国行政区划简册 [A Concise Guide to China's Administrative Divisions] (2018). Beijing: Zhongguo ditu chubanshe.

http://cpc.people.com.cn/19th

https://wenku.baidu.com/

https://icosweb.net/wp/wp-content/uploads/2019/05/ICOS-Terms-en.pdf

\section{STRESZCZENIE}

\section{CHIŃSKIE NIEURZĘDOWE NAZWY MIEJSCOWE}

Artykuł ma na celu omówienie nieurzędowych nazw miejscowych jako form odmiennych od nazw oficjalnych, analizę ich cech strukturalnych i semantycznych oraz wskazanie ich historycznych poświadczeń. Nieurzędowe chińskie nazwy miejscowe, ,przezwiska miejscowe” czy „nazwy pochwalne miast" nie powinny być definiowane jako nietypowe i nieformalne, ponieważ obecnie są one w Chinach bardzo popularne i wykorzystuje się je w sytuacjach oficjalnych. Są one nadawane przede wszystkim ważnym jednostkom miejskim, zyskującym społeczne uznanie. Większość z nich jest skonstruowana z dwóch członów. Człon pierwszy to człon odróżniający, a człon drugi to człon generyczny czy utożsamiający. Człony generyczne to terminy: 'miasto', 'stolica', 'rzeka', 'góra', 'wyspa' itp., a człony odróżniające nawiązują do roślin, zwierząt, minerałów, produktów lokalnych itp. Chińskie ,nazwy pochwalne miast” są wykorzystywane przy różnych okazjach, mają zróżnicowaną dystrybucję i różny poziom stabilności. W artykule omówiono tylko część z nich, te o stosunkowo wysokiej częstości użycia, znacznej stabilności i wyraźnej akceptacji społecznej. 
Słowa tematyczne: chińskie nazwy, nieurzędowe chińskie nazwy miejscowe, struktura chińskich nazw nieurzędowych, cechy semantyczne chińskich nazw nieurzędowych, nazwy pochwalne miast

\section{SUMMARY}

\section{CONTEMPORARY BY-NAMES OF CHINESE PLACES}

The purpose of this paper is to discuss the distinguished properties of by-names as forms different from official ones, to analyze their structural and semantic features and to search for their historical evidence. By-names of Chinese places should not be defined as unusual and informal, since actually in many cases by-names are formal and very common in China nowadays. By-names are generally bestowed on important places (mostly cities) that win the public interest. Most of them have two structural parts, the front specific parts are determiners/qualifiers and the back ones are generics. The generics generally are: cheng 城 'town/ city', $d u$ 都 'capital', jiang 江 'river', shan 山 'mountain', dao 岛 'island' etc. The lexical meanings of lexical items forming specific parts of by-names mainly refer to animals, plants, minerals, local manufactured products, climate and natural scenery, geographical location, humans, areas, etc. Chinese contemporary by-names, used on various occasions, vary in frequency and stability. The by-names discussed in the paper only account for a small proportion and are listed just due to their relatively high frequency, stability and acceptability. 